\title{
PERBEDAAN KINERJA KEUANGAN BANK OCBC NISP SEBELUM DAN SESUDAH MERGER DI INDONESIA
}

\author{
Lisa Rachel Usmany ${ }^{1}$ \\ Ida Bagus Badjra ${ }^{2}$
}

\author{
${ }^{1.2}$ Fakultas Ekonomi dan Bisnis Universitas Udayana (Unud), Bali, Indonesia \\ E-mail: lisarachel63@yahoo.com
}

\begin{abstract}
ABSTRAK
Merger adalah penggabungan dua perusahaan menjadi satu. Keputusan merger mempunyai pengaruh yang besar dalam perbaikan kondisi dan peningkatan kerja perusahaaan, karena dengan bergabungnya dua perusahaan atau lebih dapat saling menunjang kegiatan usaha, sehingga keuntungan yang dihasilkan juga lebih besar dibandingkan bila dilakukan dengan sendiri-sendiri. Tujuan dalam penelitian ini adalah untuk menganalisis apakah keputusan merger dapat meningkatkan kinerja keuangan Bank OCBC NISP dan untuk menganalisis apakah terdapat perbedaan yang signifikan kinerja keuangan Bank OCBC NISP sebelum dan sesudah merger. Penelitian ini dilakukan pada Bank OCBC NISP periode 5 tahun sebelum merger 2006-2010 dan 5 tahun setelah merger 2012-2016. Pengumpulan data menggunakan metode sensus yaitu melalui laporan keuangan bank OCBC NISP per tahun. Teknik analisis data yang digunakan adalah paried samples t-test. Berdasarkan hasil analisis ditemukan bahwa kinerja keuangan CAR, NPL, ROA dan LDR terdapat peningkatan kinerja serta terdapat perbedaan yang signifikan sebelum dan sesudah dilakukan merger.
\end{abstract}

Kata kunci: CAR, NPL, ROA, LDR, merger

\begin{abstract}
Merger is a merger of two companies into one. Merger decisions have a major influence in improving conditions and improving company employment, because with the joining of two or more companies can support each other's business activities, so that the resulting profits are also greater than if done individually. The purpose of this study is to analyze whether the merger decision can improve Bank OCBC NISP's financial performance and to analyze whether there are significant differences in Bank OCBC NISP's financial performance before and after the merger. This research was conducted at Bank OCBC NISP for a period of 5 years before the merger of 2006-2010 and 5 years after the 2012-2016 merger. Data collection uses the census method, namely through bank OCBC NISP financial statements per year. The data analysis technique used is paried samples t-test. Based on the results of the analysis it was found that the financial performance of CAR, NPL, ROA and LDR had performance improvements and there were significant differences before and after the merger.
\end{abstract}

Keywords: $C A R, N P L, R O A, L D R$, merger 


\section{PENDAHULUAN}

Setiap perusahaan memiliki tujuan yang sama yaitu memaksimalkan kekayaan pemegang saham. Globalisasi membuat perusahaan mengembangkan strategi untuk tetap dapat mengikuti persaingan (Dewi dan Trihastuti, 2016). Strategi yang dikembangkan dapat dilakukan secara internal maupun eksternal. Secara internal dilakukan dengan memperluas perusahaan dari dalam, seperti peningkatan kapasitas produksi, menambah produk, efisiensi biaya atau mencari pasar baru. Sedangkan strategi eksternal adalah meningkatkan nilai perusahaan dengan menggabungkan dua atau lebih perusahaan (Dewi dan Trihastuti, 2016).

Salah satu upaya yang dapat dilakukan yaitu dengan melakukan penggabungan usaha yang biasa disebut merger. Merger adalah salah satu strategi korporat paling banyak digunakan dan diikuti oleh organisasi untuk mencari peningkatan penciptaan nilai (Gupta, 2015). Merger didefinisikan sebagai kegiatan yang melibatkan pengambilalihan, restrukturisasi perusahaan, atau perubahan kontrol perusahaan dalam struktur kepemilikan perusahaan (Rao dan Kumar, 2013).

Merger dapat dikatakan sebagai penggabungan dua perusahaan atau lebih dengan tetap menggunakan nama salah satu perusahaan (Dewi dan Trihastuti, 2016). Jadi setelah merger perusahaan yang diambil alih dibubarkan, sedangkan perusahaan yang mengambil alih tetap beroprasi secara hukum sebagai satu badan usaha dan melanjutkan kegiatan perusahaan yang diambil alih.

Merger adalah perbuatan hukum yang dilakukan oleh satu (1) perseroan atau lebih untuk menggabungkan diri dengan perseroan lain yang telah ada yang mengakibatkan aktiva dan pasiva dari perseroan yang menggabungkan diri tersebut 
beralih karena hukum kepada perseroan yang menerima penggabungan dan selanjutnya status badan hukum perseroan yang menggabungkan diri tersebut berakhir karena hukum, menurut Undang-Undang Nomor 40 Tahun 2007 sesuai pasal 1 angka 9 tentang Perseroan Terbatas.

Maka dapat dikatakan bahwa merger merupakan suatu penggabungan dua perusahaan menjadi satu, dimana perusahaan yg menggabungkan diri membeli atau mengambil semua aset dan kewajiban yang dimiliki oleh perusahaan yang menerima merger tersebut. Keputusan merger lebih dipilih karena dengan strategi tersebut tujuan perusahaan akan cepat tercapai dibanding jika perusahaan memulai usahanya dari awal. Strategi eksternal dengan merger lebih cepat menunjukkan peningkatan dibanding strategi internal. Hal ini dianggap sesuai dengan tuntutan persaingan yang meng- haruskan perusahaan untuk menghasilkan peningkatan dengan cepat. Manfaat lain dari merger adalah adanya peningkatan skill manajerial, transfer teknologi, dan efisiensi biaya (Dewi dan Trihastuti, 2016).

Alasan perusahaan melalukan merger yaitu nilai sinergi, modal kerja, finansial, penjualan dan manajemen professional (Kamaludin dkk., 2015:30). Keputusan merger dan akuisisi juga diambil oleh perusahaan-perusahaan perbankan di Indonesia (Okalesa dkk., 2014).

Bank merupakan perusahan yang bergerak dalam bidang keuangan, artinya aktivitas perbankan selalu berkaitan dengan bidang keuangan yang didalamnya melaksanakan kegiatan menerima uang, menyimpan uang, mengedarkan uang, meminjamkan uang (Suudyasana dan Fitria, 2015). Bank sebagai lembaga keuangan berfungsi sebagai intermediasi atau perantara bagi masyarakat yang 
mempunyai dana berlebih dengan masyarakat yang membutuhkan dana (Prakoso, 2016).

Kesehatan bank dapat diartikan sebagai kemampuan suatu bank untuk melakukan kegiatan operasional perbankan secara normal dan mampu memenuhi semua kewajibannya dengan baik dengan cara-cara yang sesuai dengan peraturan perbankan yang berlaku (Widyanto, 2012). Pengertian kesehatan bank dapat disimpulkan sebagai suatu kondisi dimana bank dapat menjalankan operasionalnya secara baik, sehingga dapat menjamin kesinambungan usaha bank dan dapat mempertahankan kepercayaan masyarakat yang menanamkan dananya (Tambuwun dan Sondakh, 2015).

Tatacara penilaian kesehatan bank umum diatur dalam Peraturan Bank Indonesia Nomor 6/10/PBI/2004 tanggal 12 April 2004. Penilaian tingkat kesehatan bank dilakukan melalui penilaian kuantitatif dan penilaian kualitatif atas faktor CAMELS yaitu permodalan (Capital), kualitas aset (Asset Quality), manajemen (Management), rentabilitas (Earnings), likuiditas (Liquidity) dan sensitivitas terhadap risiko pasar (Sensitivity to Risk Market).

Penilaian faktor permodalan digunakan untuk mengetahui kecukupan modal bank dalam mendukung kegiatan operasional bank. Penilaian faktor kualitas aset digunakan untuk mengukur efisiensi manajemen dalam menggunakan aset yang dimiliki bank. Penilaian faktor rentabilitas digunakan untuk mengetahui kemampuan bank dalam menghasilkan pendapatan melalui kegiatan operasional bank. Penilaian faktor likuiditas digunakan untuk mengukur kemampuan bank dalam memenuhi kewajiban jangka pendek (Jumingan, 2006:243). 
Perekonomian Indonesia secara keseluruhan memasuki periode percepatan pertumbuhan yang positif. Perkembangan ini mendorong optimisme perbankan di tanah air untuk terus melakukan ekspansi kegiatan usahanya tanpa terkecuali Bank OCBC NISP. Direksi melakukan kajian awal dan mengambil kesimpulan bahwa perkembangan tersebut menciptakan momentum yang tepat untuk melakukan penggabungan usaha (merger) Bank OCBC NISP dan Bank OCBC Indonesia guna mencapai visi untuk menjadi bank pilihan dengan standar dunia yang diakui kepeduliannya dan terpercaya.

Sehubungan dengan penggabungan usaha (merger), direksi dari masingmasing bank peserta penggabungan melaksanakan studi kelayakan lebih mendalam. Kajian bersama ini ternyata semakin mengukuhkan kesimpulan awal bahwa penggabungan antara Bank OCBC NISP dan Bank OCBC Indonesia dapat memungkinkan bank yang menerima penggabungan untuk beroperasi sebagai satu badan hukum tunggal dengan sinergi pendapatan, biaya dan operasional sehari-hari, menghilangkan kerancuan diantara para nasabah dan pihak yang berwenang sehubungan penggunaan nama OCBC secara bersama-sama oleh Bank OCBC NISP maupun Bank OCBC Indonesia, menciptakan sinergi bisnis dimana dengan penggabungan (merger) ini menyatukan kekuatan Bank OCBC NISP di bidang pembiayaan konsumen dan komersil dengan kekuatan Bank OCBC Indonesia di bidang pembiayaan korporasi sehingga dapat melayani berbagai jenis segmentasi nasabah dengan menyediakan produk dan jasa yang lebih lengkap dan menyeluruh. menghasilkan sebuah bank yang lebih kokoh dan berdaya saing tinggi di tengahtengah persaingan perbankan yang kian kompetitif, memberikan nilai yang positif 
bagi semua pemegang saham, manajemen dan karyawan, maupun bagi keseluruhan industri perbankan di Indonesia.

Berdasarkan status dan sejarah para bank peserta penggabungan, jaringan distribusi, besarnya organisasi serta pertimbangan lainnya dari sisi keuangan dan hukum, yang material sifatnya bagi bank yang menerima penggabungan, direksi dan dewan komisaris Bank OCBC NISP maupun Bank OCBC Indonesia merekomendasikan agar Bank OCBC Indonesia digabungkan ke dalam Bank OCBC NISP.

Penelitian yang dilakukan oleh Wahasusmiah dkk. (2017), Amalia dan Ika (2014), Dewi dan Trihastuti (2016), Vinda dkk. (2016), Anthony (2017) mengatakan bahwa terdapat pengaruh yang positif pada kinerja keuangan bank setelah merger. Berbeda dengan penelitian Küçükkocaoğlu dan Bozkurt (2018), Ambika (2015) yang mengatakan bahwa tidak terdapat perbedaan pada kinerja keuangan sesudah merger.

Merger merupakan suatu bentuk penggabungan dua badan usaha, badan usaha yang satu tetap ada dan badan usaha yang satu atau yang lainnya bubar secara hukum dan nama perusahaan yang digunakan adalah nama peruahaan yang masih ada (Sutedi, 2018:85). Jadi setelah merger perusahaan yang diambil alih dibubarkan, sedangkan perusahaan yang mengambil alih tetap beroperasi secara hukum sebagai satu badan usaha dan melanjutkan kegiatan perusahaan yang diambil alih.

Merupakan penggabungan dua atau lebih perusahaan yang bergerak dalam industri yang sama dengan tujuan mengurangi persaingan atau untuk meningkatkan 
efisiensi melalui penggabungan aktivitas produksi, pemasaran, distribusi, riset dan pengembangan dan fasilitas administrasi. Dampak dari merger horisontal adalah semakin terkonsentrasinya struktur pasar pada industri tersebut. Contohnya: merger antara Bank of Tokyo dengan Mitsubishi Bank.

Terjadi apabila suatu perusahaan membeli perusahaan-perusahaan hulunya seperti perusahaan pemasoknya, dan atau perusahaan hilirnya, seperti perusahaan distribusinya yang langsung menjual produknya ke pelanggan. Merger vertikal dengan demikian merupakan penggabungan atau pengintegrasian dua tahapan produksi atau distribusi. Keuntungan dari jenis merger seperti ini adalah terjaminnya pemasokan bahan baku, penekanan biaya transaksi, terciptanya koordinasi yang lebih baik, dan mempersulit kemungkinan masuknya perusahaan pesaing yang baru. Contoh: merger antara PT Gudang Garam dengan PT Surya Pamenang sebagai perusahaan kertas.

Merupakan penggabungan dua atau lebih perusahaan yang masing-masing bergerak dalam industri yang terkait. Merger konglomerat terjadi apabila sebuah perusahaan mendiversifikasi bidang bisnisnya dalam memasuki bidang bisnis yang berbeda sama sekali dengan bisnis semula. Contoh: merger antara Viks Richardson (farmasi) dengan Procter and Gamble (Consumer Goods).

Merupakan penggabungan dua atau lebih perusahaan untuk memperluas area pasar. Adapun tujuan utamanya adalah untuk memperkuat jaringan pemasaran bagi produk masing-masing perusahaan. Biasanya merger ekstensi pasar dilakukan oleh perusahaan-perusahaan lintas negara, dalam rangka ekspansi dan penetrasi pasar serta untuk mengatasi keterbatasan ekspor karena kurang memberikan fleksibilitas 
penyediaan produk terhadap konsumen luar negeri. Contoh: merger antara Daimler Benz (Jerman) dengan Chrysler (Amerika Serikat).

Merupakan penggabungan dua atau lebih perusahaan sejenis atau dalam industri yang sama tetapi tidak memproduksi produk yang sama maupun tidak ada keterkaitan supplier. Penggabungan usaha ini dilakukan untuk memperluas lini produk masing-masing perusahaan setelah merger, perusahaan akan menawarkan lebih banyak jenis dan lini produk sehingga akan dapat menjangkau konsumen yang lebih luas.

Merger ekstensi produk ini dilakukan dengan memanfaatkan kekuatan departemen riset dan pengembangan masing-masing untuk mendapat sinergi melalui efektivitas riset sehingga lebih prodiktif dalam inovasi. Contoh: merger antara perusahaan farmasi Upjohn (Amerika Serikat) dengan Pharmacia (Swedia).

Penggabungan adalah perbuatan hukum yang dilakukan oleh satu badan usaha atau lebih, untuk menggabungkan diri dengan badan usaha lain yang telah ada yang mengakibatkan aktiva dan pasiva dari badan usaha yang menggabungkan diri beralih karena hukum kepada badan usaha yang menerima penggabungan dan selanjutnya status badan usaha yang menggabungkan diri berakhir karena hukum, hal tersebut terdapat pada pasal 1 angka (1) Peraturan Pemerintah Nomor 57 Tahun 2010 tentang Penggabungan atau Peleburan Badan Usaha dan Pengambilalihan Saham Perusahaan Yang Dapat Mengakibatkan Terjadinya Praktik Monopoli dan Persaingan Usaha Yang Tidak Sehat.

Globalisasi membuat perusahaan mengembangkan strategi untuk tetap dapat mengikuti persaingan (Dewi dan Trihastuti, 2016). Strategi yang dikembangkan 
dapat dilakukan secara internal maupun eksternal. Secara internal dilakukan dengan memperluas perusahaan dari dalam, seperti peningkatan kapasitas produksi, menambah produk, efisiensi biaya atau mencari pasar baru. Sedangkan strategi eksternal adalah meningkatkan nilai perusahaan dengan menggabungkan dua atau lebih perusahaan (Dewi dan Trihastuti, 2016).

Salah satu upaya yang dapat dilakukan yaitu dengan melakukan penggabungan usaha yang biasa disebut merger. Merger adalah salah satu strategi korporat paling banyak digunakan dan diikuti oleh organisasi untuk mencari peningkatan penciptaan nilai yang (Gupta, 2015). Keputusan untuk melakukan merger tidak sekedar menjadikan bank lebih berkembang tetapi juga untuk menciptakan nilai tambah bagi bank yang melakukan merger itu sendiri (Rizkiana dan Yuneline, 2017).

Penilaian faktor permodalan digunakan untuk mengetahui kecukupan modal bank dalam mendukung kegiatan operasional bank (Jumingan, 2006:243). Rasio yang digunakan untuk menilai Faktor Permodalan pada penelitian ini adalah capital adequacy ratio (CAR) atau kewajiban penyediaan modal minimum (KPMM). CAR merupakan rasio yang dipergunakan untuk mengukur modal guna menutupi kemungkinan kegagalan dalam pemberian kredit (Wahasusmiah dkk., 2017).

KPMM dihitung dengan membagikan Modal dengan Aktiva Tertimbang Menurut Risiko (ATMR). Modal dalam perhitungan CAR bagi bank terdiri dari modal inti dan modal pelengkap. Modal inti terdiri atas modal disetor, modal sumbangan, cadangan cadangan yang dibentuk dari laba setelah pajak. Modal pelengkap terdiri dari cadangan-cadangan yang dibentuk tidak berasal dari laba, 
modal pinjaman dan pinjaman subordinasi (Kodifikasi Peraturan Bank Indonesia, Penilaian Tingkat Kesehatan Bank). Semakin memadai rasio CAR semakin bagus kinerja perusahaan (Wahasusmiah dkk., 2017).

Penilaian faktor kualitas aset digunakan untuk mengukur efisiensi manajemen dalam menggunakan aset yang dimiliki bank (Jumingan, 2006:243). Rasio yang digunakan untuk menilai faktor kualitas aset pada penelitian ini adalah rasio non performing loan (NPL). NPL merupakan rasio untuk mengukur resiko bank atas kemungkinan tidak kembalinya kredit yang diberikan terhadap total pinjaman yang diberikan atau yang disebut dengan kredit macet (Okalesa dkk. 2014). Apabila kondisi NPL suatu bank tinggi, maka akan memperbesar pembiayaan bank, sehingga berpotensi terhadap kerugian bank (Amalia dan Ika, 2014).

Rasio rentabilitas adalah rasio yang digunakan untuk mengukur tingkat effisiensi usaha dan profibilitas yang dicapai oleh bank yang bersangkutan (Kasmir, 2012:234). Penilaian faktor rentabilitas digunakan untuk mengetahui kemampuan bank dalam menghasilkan pendapatan melalui kegiatan operasional bank (Jumingan, 2006:243). Rasio yang digunakan untuk menilai faktor rentabilitas pada penelitian ini adalah rasio return on asset (ROA).

ROA merupakan rasio yang digunakan untuk mengetahui kemampuan bank menghasilkan keuntungan secara relatif dibandingkan dengan nilai total aset-nya (Dewi dan Trihastuti, 2016). ROA menunjukkan keefektifan bank dalam memanfaatkan seluruh sumber daya atau aset yang dimiliki (Okalesa dkk., 2014). 
Semakin besar ROA suatu bank, semakin besar pula tingkat keuntungan yang dicapai bank (Amalia dan Ika, 2014).

Penilaian faktor likuiditas digunakan untuk mengukur kemampuan perusahaan untuk memenuhi kewajiban finansial yang jatuh tempo dalam jangka pendek (Suudyasana dan Fitria, 2015). Rasio yang digunakan untuk menilai faktor likuiditas pada penelitian ini adalah loan to deposit ratio (LDR). LDR merupakan rasio yang digunakan untuk mengukur komposisi jumlah kredit yang diberikan dibandingkan dengan jumlah dana masyarakat dan modal sendiri yang digunakan (Wahasusmiah dkk., 2017).

Semakin besar rasio LDR menunjukkan bahwa banyaknya pemberian kredit yang disalurkan oleh bank ke nasabah meningkat dan ini menimbulkan kepercayaan nasabah kepada bank dalam meminjam uang ke bank dan pihak bank mendapatkan keuntungan bunga sehingga mampu menciptakan laba dan mampu meningkatkan kinerja perusahaan, sebaliknya jika rasio LDR menurun maka akan menurunkan keuntungan dari bunga atas berkurangnya pendapatan atas pinjaman nasabah (Wahasusmiah dkk., 2017).

Beberapa penelitian mengenai kinerja keuangan sebelum dan sesudah merger yang menyatakan bahwa terdapat perbedaan yang signifikan pada kinerja keuangan sebelum dan sesudah dilakukan merger pada semua periode pengamatan dan pengujian. Penelitian ini juga didukung oleh (Wahasusmiah dkk., 2017), Amalia dan Ika (2014), Dewi dan Trihastuti (2016), (Vinda dkk., 2016), Anthony (2017) mengatakan bahwa terdapat pengaruh yang positif pada kinerja keuangan bank 
setelah merger. Berdasarkan landasan teori dan kerangka berpikir diatas, maka dapat diajukan hipotesis sebagai berikut :

$\mathrm{H}_{1}$ : Terdapat perbedaan yang signifikan pada tingkat kinerja keuangan bank OCBC NISP sebelum dan sesudah merger.

\section{METODE PENELITIAN}

Ruang lingkup wilayah penelitian ini adalah pada sektor perbankan per tahun, periode 5 tahun sebelum merger yaitu tahun 2006-2010 dengan cut off pada tahun 2011 dan 5 tahun sesudah merger yaitu 2012-2016 yang terdaftar di Bursa Efek Indonesia (BEI). Data dokumentasi tersebut diperoleh dari PT. BANK OCBC NISP Tbk.

CAR dapat diukur dengan formula (Riyadi, 2006:161) :

$$
\mathrm{CAR}=\frac{\text { Modal }}{\begin{array}{c}
\text { Aktiva Tertimbang Menurut Resiko } \\
\text { (ATMR) }
\end{array}} \times 100 \%
$$

Berdasarkan lampiran surat edaran Bank Indonesia nomor 13/30/Dpnp Tanggal 16 Desember 2011 NPL dapat diukur dengan formula :

$$
\mathrm{NPL}=\frac{\text { Kredit Bermasalah }}{\text { Total Kredit }} \times 100 \%
$$

Rasio yang digunakan untuk menilai faktor rentabilitas pada penelitian ini adalah rasio return on asset (ROA) periode 5 tahun sebelum merger yaitu tahun 2006-2010 dan 5 tahun sesudah merger yaitu tahun 2012-2016 pada Bank OCBC NISP dengan menggunakan persentase sebagai satuan pengukuran. ROA dapat diukur dengan formula (Riyadi, 2006:156) :

$$
\mathrm{ROA}=\frac{\text { Laba Sebelum Pajak }}{\text { Total Aset }} \times 100 \%
$$

\subsubsection{Likuiditas (Liquidity)}

LDR dapat dihitung dengan formula (Riyadi, 2006:165) : 


$$
\mathrm{LDR}=\frac{\text { Total Kredit yang Diberikan }}{\text { Total Dana Pihak Ketiga }} \times 100 \%
$$

Perbedaan kinerja keuangan sebelum dan sesudah merger dapat diuji dengan menggunakan paried samples t-test. Dilakukan dengan cara membandingkan perbandingan rasio kinerja keuangan sebelum dan sesudah dilakukan merger. Pengambilan keputusan didasarkan pada sig. (2-tailed) dengan tingkat signifikansi $($ alpha $=0,05)$ yang digunakan dalam penelitian ini. Prasyarat untuk melakukan pengujian beda dua rata-rata adalah dilakukannya uji normalitas dengan menggunakan Kolmogorov-Smirnov sebelum menguji perbedaan rasio kinerja keuangan. Jika model dalam penelitian memiliki data yang berdistribusi normal maka pengujian akan dilakukan menggunakan uji parametrik. Namun jika sebaliknya maka pengujian akan dilakukan dengan uji nonparametrik.

Rumus uji t sebagai berikut :

$\frac{\bar{x} 1-\bar{x} 2}{S d / \sqrt{n}}$

Keterangan :

$\bar{x} 1$ : Rata-rata variabel pengamatan sebelum merger

$\bar{x} 2$ : Rata-rata variabel pengamatan sesudah merger

$\mathrm{Sd}$ : Standar deviasi sampel

$\mathrm{n} \quad$ : Jumlah pengamatan sampel

\section{HASIL DAN PEMBAHASAN}

Analisis data deskriptif dilakukan untuk mendapatkan informasi tentang kinerja keuangan sebelum dan sesudah dilakukannya merger. Kinerja keuangan terdiri dari capital adequacy ratio (CAR), non performing loan (NPL), return on asset (ROA), loan to deposit ratio (LDR). 
Capital adequacy ratio (CAR) merupakan rasio yang dipergunakan untuk mengukur modal guna menutupi kemungkinan kegagalan dalam pemberian kredit (Wahasusmiah dkk., 2017). Dapat dilihat pada tabel 1 bahwa hasil rata-rata perhitungan CAR Bank OCBC NISP sebelum melakukan merger sebesar 14,1 persen dan sesudah melakukan merger CAR mengalami peningkatan menjadi sebesar 17,9 persen yang diperoleh dari lampiran 1 yang diolah. Data rata-rata diatas menunjukkan nilai CAR Bank OCBC NISP setelah merger cenderung lebih besar dibandingkan dengan rata-rata CAR sebelum merger.

Tabel 1.

Capital Adequacy Ratio Bank OCBC NISP

\begin{tabular}{cccc}
\hline \multicolumn{2}{c}{ Capital Adequacy Ratio } \\
Sebelum Merger & \multicolumn{2}{c}{ Sesudah Merger } \\
\hline Tahun & CAR & Tahun & CAR \\
$\mathbf{2 0 0 6}$ & $11,8 \%$ & 2012 & $14,9 \%$ \\
$\mathbf{2 0 0 7}$ & $14,0 \%$ & 2013 & $18,2 \%$ \\
$\mathbf{2 0 0 8}$ & $14,7 \%$ & 2014 & $19,9 \%$ \\
$\mathbf{2 0 0 9}$ & $15,2 \%$ & 2015 & $18,1 \%$ \\
$\mathbf{2 0 1 0}$ & $14,9 \%$ & 2016 & $18,2 \%$ \\
$X$ & CAR & $\mathbf{X}$ CAR & $17,9 \%$ \\
\hline
\end{tabular}

Sumber: Data diolah, 2018

\begin{tabular}{cccc}
\hline \multicolumn{3}{c}{ Non Performing Loan } & \multicolumn{2}{c}{ Sesudah Merger } \\
\hline Sebelum Merger & NPL & Tahun & NPL \\
Tahun & $2,53 \%$ & 2012 & $0,91 \%$ \\
$\mathbf{2 0 0 6}$ & $2,57 \%$ & 2013 & $0,73 \%$ \\
$\mathbf{2 0 0 7}$ & $2,80 \%$ & 2014 & $1,34 \%$ \\
$\mathbf{2 0 0 8}$ & $1,60 \%$ & 2015 & $1,30 \%$ \\
$\mathbf{2 0 0 9}$ & $1,60 \%$ & 2016 & $0,19 \%$ \\
$\mathbf{2 0 1 0}$ & $2,22 \%$ & $\bar{X}$ NPL & $0,89 \%$ \\
\hline $\bar{X}$ NPL & &
\end{tabular}

Aspek penilaian faktor permodalan yang diukur dengan menggunakan CAR menunjukkan bahwa adanya peningkatan kinerja keuangan bank OCBC NISP setelah keputusan merger.

Tabel 2. Sumber: Data diolah, 2018

\section{Non Performing Loan Bank OCBC NISP}


Non performing loan (NPL) merupakan rasio untuk mengukur resiko bank atas kemungkinan tidak kembalinya kredit yang diberikan terhadap total pinjaman yang diberikan atau yang disebut dengan kredit macet (Okalesa dkk., 2014). Dapat dilihat pada Tabel 2. bahwa hasil rata-rata perhitungan NPL Bank OCBC NISP sebelum melakukan merger sebesar 2,22 persen dan sesudah melakukan merger NPL mengalami penurunan menjadi 0,89 persen yang diperoleh dari lampiran 2 yang diolah.

Data rata-rata diatas menunjukkan nilai NPL Bank OCBC NISP setelah merger cenderung lebih kecil dibandingkan dengan rata-rata NPL sebelum merger.

\begin{tabular}{cccc}
\hline \multicolumn{2}{c}{ Sebelum Merger } & \multicolumn{2}{c}{ Return On Asset } \\
\hline Tahun & ROA & Tahun & ROA \\
$\mathbf{2 0 0 6}$ & $1,38 \%$ & 2012 & $1,54 \%$ \\
$\mathbf{2 0 0 7}$ & $1,22 \%$ & 2013 & $1,57 \%$ \\
$\mathbf{2 0 0 8}$ & $1,33 \%$ & 2014 & $1,72 \%$ \\
$\mathbf{2 0 0 9}$ & $1,37 \%$ & 2015 & $1,64 \%$ \\
$\mathbf{2 0 1 0}$ & $1,13 \%$ & 2016 & $1,70 \%$ \\
\hline $\bar{X}$ ROA & $1,28 \%$ & $\bar{X}$ ROA & $1,63 \%$ \\
\hline
\end{tabular}

Hal ini menunjukkan bahwa adanya peningkatan kinerja keuangan Bank OCBC NISP setelah keputusan merger, karena adanya kredit yang bermasalah pada bank menurun setelah dilakukan merger.

Tabel 3. Return on Aset Bank OCBC NISP

Sumber: Data diolah, 2018

Return on aset ROA merupakan rasio yang digunakan untuk mengetahui kemampuan bank menghasilkan keuntungan secara relatif dibandingkan dengan nilai total aset-nya (Dewi dan Trihastuti, 2016). Dapat dilihat pada Tabel 3. bahwa hasil rata-rata perhitungan ROA Bank OCBC NISP sebelum melakukan merger 
sebesar 1,28 persen dan sesudah melakukan merger ROA mengalami peningkatan menjadi 1,63 persen.

Data rata-rata diatas menunjukkan nilai ROA Bank OCBC NISP setelah merger cenderung lebih besar dibandingkan dengan rata-rata ROA sebelum merger. Aspek penilaian tingkat profitabilitas yang dicapai oleh bank yang diukur dengan menggunakan ROA menunjukkan bahwa adanya peningkatan kinerja keuangan Bank OCBC NISP setelah keputusan merger. Hal ini berarti kemampuan bank dalam menghasilkan laba menjadi semakin baik.

Tabel 4.

Loan to Deposit Ratio Bank OCBC NISP

\begin{tabular}{cccc}
\hline \multicolumn{4}{c}{ Loan to Deposit Ratio } \\
\hline Tahun & \multicolumn{2}{c}{ Sesudah Merger } \\
$\mathbf{2 0 0 6}$ & LDR & Tahun & LDR \\
$\mathbf{2 0 0 7}$ & $77,8 \%$ & 2012 & $85,4 \%$ \\
$\mathbf{2 0 0 8}$ & $82,7 \%$ & 2013 & $90,9 \%$ \\
$\mathbf{2 0 0 9}$ & $74,1 \%$ & 2014 & $108,8 \%$ \\
$\mathbf{2 0 1 0}$ & $71,3 \%$ & 2015 & $96,2 \%$ \\
$X$ & $78,4 \%$ & 2016 & $87,1 \%$ \\
LDR & $76,8 \%$ & $X$ & $93,7 \%$ \\
\hline
\end{tabular}

Sumber: Data diolah, 2018

Loan to deposit ratio (LDR) merupakan rasio yang digunakan untuk mengukur komposisi jumlah kredit yang diberikan dibandingkan dengan jumlah dana masyarakat dan modal sendiri yang digunakan (Wahasusmiah dkk., 2017). Dapat dilihat pada Tabel 4. bahwa hasil rata-rata perhitungan LDR Bank OCBC NISP sebelum melakukan merger sebesar 76,8 persen dan sesudah melakukan merger LDR mengalami peningkatan menjadi 93,7 persen yang diperoleh dari lampiran 4 yang diolah. Data rata-rata diatas menunjukkan nilai LDR Bank OCBC NISP setelah merger cenderung lebih besar dibandingkan dengan rata-rata LDR sebelum merger. 
Aspek penilaian tingkat likuiditas yang dicapai oleh bank yang diukur dengan menggunakan LDR, menunjukkan bahwa adanya peningkatan kinerja keuangan Bank OCBC NISP setelah keputusan merger. Hal ini berarti kemampuan bank dalam memenuhi kewajiban jangka pendeknya menjadi semakin baik.

Tabel 5.

Hasil Uji Statistik Deskriptif Kinerja Keuangan Bank OCBC NISP Sebelum dan Sesudah Merger

\begin{tabular}{llllll}
\hline & N & Minimum & Maximum & Mean & $\begin{array}{l}\text { Std. } \\
\text { Deviation }\end{array}$ \\
\hline CAR Sebelum & 5 & .11798 & .15188 & .1413647 & .01380046 \\
CAR Sesudah & 5 & .14948 & .19919 & .1789874 & .01809117 \\
NPL Sebelum & 5 & .01599 & .02795 & .0221855 & .00574501 \\
NPL Sesudah & 5 & .00188 & .01340 & .0089462 & .00471849 \\
ROA Sebelum & 5 & .01130 & .01375 & .0128323 & .00107221 \\
ROA Sesudah & 5 & .01544 & .01723 & .0163540 & .00078750 \\
LDR Sebelum & 5 & .71313 & .82746 & .7686444 & .04372613 \\
LDR Sesudah & 5 & .85374 & 1.08772 & .9370856 & .09402636 \\
\hline
\end{tabular}

Sumber: Data diolah, 2018

CAR sebelum merger memiliki nilai minimum sebesar 0,11798 nilai maksimum sebesar 0,15188 dan nilai standar deviasi 0,01380046. CAR sesudah merger memiliki nilai minimum sebesar 0,14948 nilai maksimum sebesar 0,19919 dan nilai standar deviasi 0,01809117. NPL sebelum merger memiliki nilai minimum sebesar 0,01599 nilai maksimum sebesar 0,02795 dan nilai standar deviasi 0,00574501. NPL sesudah merger memiliki nilai minimum sebesar 0,00188 nilai maksimum sebesar 0,01340 dan nilai standar deviasi 0,00471849 . ROA sebelum merger memiliki nilai minimum sebesar 0,01130 nilai maksimum sebesar 0,01375 dan nilai standar deviasi 0,00107221 .

ROA sesudah merger memiliki nilai minimum sebesar 0,01544 nilai maksimum sebesar 0,01723 dan nilai standar deviasi 0,00078750. LDR sebelum 
merger memiliki nilai minimum sebesar 0,71313 nilai maksimum sebesar 0,82746 dan nilai standar deviasi 0,04372613 . LDR sesudah merger memiliki nilai minimum sebesar 0,85374 nilai maksimum sebesar 1,08772 dan nilai standar deviasi 0,09402636.

Uji normalitas digunakan untuk mengetahui apakah data uji berdistribusi normal atau tidak. Data akan dikatakan berdistribusi normal jika nilai Asymp.sig (2tailed) $>\alpha=5$ persen. Hasil pengujian normalitas data disajikan pada tabel 6 berikut ini:

Tabel 6.

Hasil uji normalitas data rasio keuangan bank OCBC NISP

\begin{tabular}{lccc}
\hline & N & Kolmogorov-Smirnov Test & Asymp. Sig. (2-tailed) \\
\hline CAR Sebelum & 5 & .607 & .855 \\
CAR Sesudah & 5 & .777 & .583 \\
NPL Sebelum & 5 & .683 & .739 \\
NPL Sesudah & 5 & .461 & .984 \\
ROA Sebelum & 5 & .573 & .898 \\
ROA Sesudah & 5 & .452 & .987 \\
LDR Sebelum & 5 & .408 & .996 \\
LDR Sesudah & 5 & .480 & .975 \\
\hline
\end{tabular}

Sumber: Data diolah, 2018

Berdasarkan output SPSS pada Tabel 6. terlihat bahwa CAR sebelum merger dan sesudah merger berdistribusi normal dengan Asymp.sig (2-tailed) $>\alpha$ yaitu sebelum merger sebesar 0,855 dan sesudah merger sebesar 0,583. NPL berdistribusi normal sebelum dan sesudah merger dengan Asymp.sig (2-tailed) $>\alpha$ yaitu sebelum merger sebesar 0,739 dan sesudah merger sebesar 0,984. ROA berdistribusi normal dengan Asymp.sig (2-tailed) $>\alpha$ yaitu sebelum merger sebesar 0,898 dan sesudah merger sebesar 0,987 . LDR berdistribusi normal dengan Asymp.sig (2-tailed) > $\alpha$ yaitu sebelum merger sebesar 0,996 dan sesudah merger sebesar 0,975 . 
Hasil uji beda yang digunakan untuk menganalisis ada tidaknya perbedaan kinerja keuangan sebelum dan sesudah dilakukannya merger adalah uji beda paired sample t-test hal ini karena ada data sebelum dan sesudah dilakukannya merger terdistribusi secara normal. Hasil uji beda dapat dilihat pada tabel 7.

Tabel 7.

Hasil uji beda dua sampel berpasangan

\begin{tabular}{cccc}
\hline No & Variabel & t hitung & Sig. (2-tailed) \\
\hline 1. & CAR & -9.056 & 0.001 \\
2. & NPL & 4.950 & 0.008 \\
3. & ROA & -5.243 & 0.006 \\
4. & LDR & -3.048 & 0.038 \\
\hline
\end{tabular}

Sumber: Data diolah, 2018

Pada NPL hasil analisis uji beda menjunjukkan hasil Sig. (2-tailed) 0,008 dengan signifikansi 0,05 maka $\mathrm{H}_{0}$ ditolak dan $\mathrm{H}_{1}$ diterima, berarti bahwa terdapat perbedaan yang signifikan pada kinerja keuangan sebelum dan sesudah terjadinya merger. Hal ini menunjukkan bahwa adanya kredit yang bermasalah pada bank menurun setelah dilakukan merger. Hasil penelitian ini di dukung oleh Xu (2015), Amalia dan Ika (2014), Shrestha et al. (2017) dan Sharma (2017).

Hasil uji beda ROA menunjukkan nilai Sig. (2-tailed) 0,006 dengan signifikansi 0,05 maka $\mathrm{H}_{0}$ ditolak dan $\mathrm{H}_{1}$ diterima, berarti bahwa terdapat perbedaan yang signifikan pada kinerja keuangan sebelum dan sesudah terjadinya merger. Hal ini menunjukkan bahwa kemampuan bank dalam menghasilkan laba menjadi semakin baik. Penelitian ini didukung oleh Sujud dan Hachem (2018), Cahyati (2012), Rizkiana dan Yuneline (2017), Salim (2018) dan Tanwar (2016).

Pada LDR hasil analisis uji beda menunjukkan hasil Sig. (2-tailed) 0,038 dengan signifikansi 0,05 maka $\mathrm{H}_{0}$ ditolak dan $\mathrm{H}_{1}$ diterima, berarti bahwa terdapat 
perbedaan yang signifikan pada kinerja keuangan sebelum dan sesudah terjadinya merger. Hal ini menunjukkan bahwa kemampuan bank dalam memenuhi kewajiban jangka pendeknya menjadi semakin baik. Penelitian ini didukung oleh Cahyati (2012), Prima (2018), Putra dkk. (2018) dan Abdulwahab dan Ganguli (2017).

Hasil penelitian ini menyatakan bahwa terdapat perbedaan yang signifikan pada tingkat kinerja keuangan bank OCBC NISP sebelum dan sesudah merger. Bukti empiris yang diperoleh melalui penelitian ini menunjukkan bahwa CAR, NPL, ROA dan LDR menjadi lebih baik setelah dilakukan merger. Hasil penelitian ini dapat digunakan untuk mendukung teori-teori yang sudah ada, bahwa merger merupakan salah satu strategi perusahaan atau bank yang dapat dijadikan alternatif untuk meningkatkan kinerjanya.

Hasil penelitian ini dapat digunakan sebagai literatur untuk memahami merger melalui pengalaman penelitian ini. Strategi merger ini dapat digunakan untuk memperoleh keuntungan yang lebih besar dibandingkan jika perusahaan tersebut melakukan usaha sendiri-sendiri. Penelitian ini juga dapat digunakan manajer dalam pengambilan keputusan bisnis. Baik manajer maupun investor juga dapat menggunakan CAR, NPL, ROA dan LDR untuk menganalisis kinerja keuangan bank.

\section{SIMPULAN}

Kinerja keuangan yang diukur dengan CAR, NPL, ROA dan LDR menunjukkan bahwa keputusan merger dapat meningkatkan kinerja keuangan pada Bank OCBC NISP sebelum dan sesudah merger. Hasil analisis uji beda CAR, NPL, ROA dan LDR menjunjukkan adanya perbedaan yang signifikan pada kinerja 
keuangan Bank OCBC NISP sebelum dan sesudah merger. Hasil penelitian ini mendukung hipotesis yang telah dikemukakan, hal ini berarti kinerja keuangan Bank OCBC NISP menjadi lebih baik dibandingkan dengan sebelum dilakukannya merger.

Bagi peneliti lain yang ingin meneliti topik yang sama, sebaiknya mengambil periode waktu yang lebih panjang agar diperoleh hasil yang lebih akurat. Bagi peneliti selanjutnya juga disarankan untuk meneliti bank bank lain yang melakukan merger dan menambah variabel kinerja keuangan penelitian.

Bagi perusahaan yang akan melakukan merger sebaiknya melakukan persiapan yang baik sebelum memutuskan untuk melakukan merger, seperti melihat kondisi perusahaan dari segi manajemen maupun finansial perusahaan.

Bagi investor sebaiknya lebih berhati hati dalam menginvestasikan dananya pada perusahaan yang melakukan merger, karena kegiatan tersebut tidak selalu membawa dampak yang lebih baik bagi perusahaan. Sehingga investor diharapkan lebih teliti dalam melakukan analisis keuangan suatu perusahaan.

\section{REFERENSI}

Abdulwahab, Bushra A., dan Ganguli, Subhadra. (2017). The Impact of Mergers and Acquisitions on Financial Performance of Banks in the Kingdom of Bahrain during 2004-15. Information Management and Business Review. 9 (4). 34-45.

Amalia, Firda., dan Ika, Siti Rochmah. (2014). Kinerja Bank Di Indonesia Setelah Melakukan Merger Dan Akuisisi Dengan Kepemilikan Asing: Apakah Lebih Baik?. Efektif Jurnal Bisnis dan Ekonomi. 5 (1). 73-84.

Ambika, Achini. (2015). A Study on Merger of ICICI Bank and Bank of Rajasthan. SUMEDHA Journal of Management. 4 (3). 124-136. 
Anthony, Mugo. (2017). Effects of Merger and Acquisition on Financial Performance: Case Study of Commercial Banks. Internasional Journal of Business Management \& Finance. 1 (6). 93-105.

Cahyati, Endah Noer. (2012). Analisis Kinerja Keuangan Sebelum Dan Setelah Merger Pada Pt. Bank Ocbc Nisp, Tbk Dan Bank Ocbc Indonesia. Jurnal Fakultas Ekonomi. 2 (3). 1-20.

Devarajappa, S. (2017). A Study on Financial Performance of Merged Indian Commercial Banks: A CAMEL Approach. Splint International Journal of Professionals . 4 (6).7-19.

Dewi, Mergareta Selianan., dan Trihastuti, Adiati. (2016). Penilaian Kualitas Kinerja Keuangan Perusahaan Perbankan Antara Sebelum Dan Sesudah Merger Studi Kasus Pada Pt. Bank Mandiri, Tbk. Jurnal Ekonomi Akuntansi. 1 (1). 21-36.

Gupta, Komal., (2015). Mergers And Acquisitions In The Indian Banking Sector: A Study Of Selected Banks. International Journal of Advanced Research in Management and Social Science. 4 (3). 94-107.

Jumingan. 2006. Analisis Laporan Keuangan. Jakarta: PT. Bumi Aksara.

Kasmir. 2012. Analisis Laporan Keuangan. Rajawali Pers, Jakarta

Kamaludin., Susena, Karona Cahya., dan Usman, Berto. 2015. Restrukturasi Merger \& Akuisisi. Mandar Maju, Bandung.

Kodifikasi Peraturan Bank Indonesia, Penilaian Tingkat Kesehatan Bank diakses dari http://www.bi.go.id

Küçükkocaoğlu, Güray., dan Bozkurt, Melike Aktaş. (2018). Identifying The Effects Of Mergers And Acquisitions On Turkish Banks' Performances. Asian Journal of Economic Modelling. 6 (3). 235-244.

Okalesa., Efni, Yulia., dan Zulbahridar. (2014). Analisis Perbandingan Kinerja Keuangan Perusahaan Perbankan Yang Go Publik Di Bursa Efek Indonesia Sebelum dan Sesudah Merger dan Akuisisi Periode Tahun 20002012. Jurnal Tepak Manajemen Bisnis. 6 (3). 90-104.

Prakoso, Ockto Dinar Alan. (2016). Analisis Kinerja Keuangan Sebelum dan SESUDAH Merger Pada PT Bank OCBC NISP. Jurnal Ilmu dan Riset Manajemen. 5 (6). 1-19.

Prima, Arient Bella. (2018). Analisis Kinerja Keuangan Bank Di Indonesia Sebelum Dan Sesudah Merger (Studi Pada Perusahaan Domestik Yang 
Merger Dengan Kepemilikan Asing). Jurnal Ilmiah Mahasiswa FEB. 6 (2). 63-79.

Putra, Nicky Irawan., Siregar, Hermanto., dan Johan, Suwinto. (2018). The Influence Of Mergers And Acquisitions On Financial Performance And Stock Return Of Indonesian Banks. European Journal of Accounting, Auditing and Finance Research. 6 (4). 79-94.

Rao, S. Durga., dan Kumar, Prasantha. (2013). Financial Performance Evaluation of Indian Commercial Banks during Before and After Mergers. SUMEDHA Journal of Management. 2 (1). 117-129.

Riyadi, Selamet. 2006. Banking Assets And Liability Management. Edisi Ketiga. Jakarta: Lembaga Penerbit Fakultas Ekonomi Universitas Indonesia.

Rizkiana, Nurul., dan Yuneline, Mirza Hedismarline. (2017). Komparasi Kinerja Keuangan Sebelum dan Sesudah Merger dengan Rasio Keuangan dan Metode Economic Value Added pada PT. Bank OCBC NISP, Tbk. Journal Banking and Management Review. 6 (1). 748-766.

Salim, Savina. (2018). Analisis Kinerja Sebelum Dan Sesudah Merger Akuisisi Perbankan Indonesia. Jurnal Manajemen Bisnis Dan Kewirausahaan. 3 (1). 145-163.

Samuila, Anderibum Asauten., dan Christopher, Obute O. (2015). The Effects Of Mergers And Acquisitions On The Performanceof Commercial Banks In Nigeria: Evidenced From United Bank For Africa (Uba) Plc. International Journal of Education and Research. 3 (4). 93-122.

Sharma, Krishna Prasad. (2017). Effect Of Banks' Merger And Acquisition In Nepal: Study Of Selected Banks. Kaav International Journal Of Law, Finance \& Industrial Relations. 5 (1). 41-52.

Shrestha, Magina., Thapa, Ram Kumar., dan Phuyal, Ram Kumar. (2017). A Comparative Study of Merger Effect on Financial Performance of Banking and Financial Institutions in Nepal. Journal of Business and Social Sciences Research (JBSSR). 2 (1\&2). 47-68.

Sujud, Hiyam.,dan Hachem, Boutheina. (2018). Effect of Mergers and Acquisitions on Performance of Lebanese Banks. International Research Journal of Finance and Economics. 1 (166). 70-77.

Sutedi, Adrian. 2018. Hukum Perbankan Suatu Tinjauan Pencucian Uang, Merger, Likuidasi dan Kepailitan. Jakarta: Sinar Grafika.

Suudyasana, Ayu., dan Fitria, Astri. (2015). Analisis Perbedaan Kinerja Keuangan Sebelum dan Sesudah Merger. Jurnal Ilmu \& Riset Akuntansi. 4 (3). 1-20. 
Tambuwun, Candri J., dan Sondakh, Jullie J. (2015). Analisis Laporan Keuangan Sebagai Ukuran Kesehatan Bank Dengan Metode Camel Pada Pt. Bank Sulut. Jurnal EMBA. 3 (2). 863-873.

Tanwar, Nidhi. (2016). A study on the performance analysis of banks in India after mergers and acquisitions. International Journal of Commerce and Management Research. 2 (12). 37-40.

Undang-Undang Nomor 40 Tahun 2007 tentang Perseroan Terbatas.

Veena, K.P., dan Patti, S.N. (2017). Pre and Post Merger Performance through CAMEL Rating Approach: A Case Study of ICICI Bank Ltd. International Journal of Engineering and Management Research. 7 (4). 84-92.

Vinda, Warikkie Tiara Intan., Mangantar, Marjam., dan Sumarauw, Jacky S.B. (2016). Perbandingan Kinerja Keuangan Pada Pt.Bank Cimb Niaga.Tbk Dan Pt.Bank Ocbc Nisp.Tbk Periode Tahun 2013 -2014. Jurnal Berkala Ilmiah Efisiensi. 16 (1). 903-919.

Wahasusmiah, Rolia., Widyanti, Yeni., dan Wati, Trisnina. (2017). Analisis Strategi Corporation Melalui Merger Dan Akuisisi Terhadap Kinerja Perusahaan Perbankan. Jurnal Sosial, Ekonomi, dan Humaniora. 7 (2). 344-356.

Widyanto, Eko Adi. (2012). Analisis Tingkat Kesehatan Dan Kinerja Keuangan Bank Dengan Menggunakan Metode Camel (Studi Kasus Pada Pt. Bank Mega Syariah Indonesia Periode 2008-2010). Jurnal Eksis. 8 (2). 21682357.

Xu, Jiyun., Gan, Christopher., dan Hu, Baiding. (2015). An empirical analysis of China's Big four state-owned banks' performance: A data envelopment analysis. Journal of Banking Regulation. 16 (1). 1-21. 